\title{
"I think that poets and, more broadly, all artists have some certain cognitive impatience in them"
}

\section{An Interview with Professor Jerzy Kandziora about Stanisław Barańczak, Conducted by Karolina Król}

\section{S UM MARY}

The interview covers the subject of Stanisław Barańczak and his works. Pondering on the way the poet pictures the existence of God in his poems is an important part of the text. Another crucial subject is the way Barańczak deals with his illness and portrays it in his poetic works. In the interview Jerzy Kandziora - an exquisite reasercher of the poetry written by Barańczak and Jerzy Ficowski - mentions his private relationship with both Barańczak and his wife.

\section{Keywords}

Stanisław Barańczak, poetry, illness, God

Karolina Król: How did you meet Professor Barańczak? During the discussion panel devoted to this poet, you mentioned that initially your relationship was established on official university grounds. When did this relationship shift to the personal level? 
Jerzy Kandziora: I started my studies in 1973. Stanisław Barańczak and his wife Anna were then employed as assistant lecturers at the Polish Philology in Poznań. At the end of 1973, Barańczak received his doctorate on the basis of his doctoral dissertation on Miron Białoszewski. On a private basis, we met after I had completed my studies in 1977. Barańczak had already been a member of the Workers' Defence Committee and he had been removed from his work at the university, against which we, students, protested by signing a joint letter. I should speak for myself, but I could testify that, as students, we were all deeply concerned about the dismissal of Barańczak from the university. When we left the auditorium after the graduation, I approached Ania and Staszek - still for me Dr Barańczak and his wife - and handed them my graduate flowers. I was extremely excited and, at the same time, uncomfortable so I was only able to say a few words of thanks for his opposition activities. Barańczak somehow managed to relieve my tension. We talked for some time and it became clear that Staszek and Ania wanted me to visit them in private. After that, my visits to them began, first in Staszek's mother's flat, on Kościuszki Street, and later in the Kopernika estate. We met till the Barańczaks headed for the United States in March 1981.

K.K.: Did you visit them in the USA?

J.K.: No, I did not visit them, but we kept in touch through correspondence. Initially, the exchange of letters was quite intensive, as it was also connected to professional matters, the registration of his foreign publications for the Polish Literary Bibliography, in the team of which I worked at that time. Besides, thanks to Staszek, I received copies of some of his books from the publishers, such as Tablica z Macondo [A License Plate from Macondo], translations of English-language poetry or Shakespeare. I, in turn, gave him my texts on his poetry.

K.K.: Did Barańczak comment on them in any way?

J.K.: He did. On the one hand, I regret that I did not bring these letters with me today to show you. On the other hand, perhaps it is better because they were full of kindness and compliments, and it does not seem appropriate to boast too much. On a more serious note, Barańczak liked what I wrote about his poetry. I sent him early excerpts from my later book about him published in magazines. He reacted very spontaneously. It seemed he somehow needed my writing. I also sent him my reflections on poems by Merrill in his translation, which he received very kindly.

K.K.: Did he in any way take these comments into account? In his correspondence with Miłosz, there are also references to various translations, but Barańczak never used the advice given by the Nobel Prize winner. How was it in this case? 
J.K.: No, that was not an option at all. Barańczak never asked for any comments, I was simply reacting to his texts which had already been published. As for his relationship with Miłosz, I think that he did not want to give in to any suggestions made by others, and that possible questions about his opinion might have been more of a courtesy. But that is just my hypothesis. What is interesting, however, is that in response to my ideas about reading his texts, he would make his own self-interpretations. I was looking through our correspondence the other day and realised how extensive those self-interpretations were: one was a page and a half long. I may one day decide to publish these letters, but for the time being I am not quite ready to do so. Too little time has passed since Stanisław's death.

I exchanged the bulk of the letters with Barańczak in the period following his departure until the symptoms of his illness got more severe. Over time, all selfless friendly correspondence faded into the background, as the disease forced Staszek to keep it to a minimum. And yet, even in this difficult period, he was able to send a single poem or translation, signed less and less legibly, as a sign of friendship.

For me, the most important period of our friendship was after 1977 till 1981 when I was able to meet with the Barańczaks in person in their flat. That was the period, to be more precise, until August 1980 when Staszek was 'illegal', surveilled, bugged, and when my visits at his place were of great significance to me. I felt that it would be wrong of me if I did not call on Ania and Staszek. In the beginning, there were two parallel feelings. On the one hand, it was simply human fear. I was aware that I was inevitably getting into police records. It was a completely new experience for me. At the same time, I could not stop going to Ania and Staszek Barańczak because I simply needed it, and it seemed to straighten me out in terms of my own dignity. After every visit I felt that I had overcome this fear, that I was myself, that I was not losing my identity because of it. I felt lifted up, as I recall.

K.K.: Could having contact with Barańczak alone be dangerous?

J.K.: I was aware that I was putting myself at risk in a way by contacting him. The Security Service followed all his activities. Shortly afterwards, I was summoned to the provincial police headquarters where attempts were made to interrogate me and I was offered in a veiled manner to snitch on others. Back then, in 1978, such a summons was very stressful, although I had already known how to deal with informal summons, that they should be questioned and that they could be grounds for refusing to answer questions. And that was what I stuck to. There were also visits made by officers to my place of work, signalling to my superiors that there was a 'threat' on my part. At the time, the problem was that I felt somewhat lonely: I did not want to say anything to my parents so as not to worry them.

K.K.: Did your conversations with the Barańczaks concern everyday life? Or were they perhaps rather focused on literature-related themes? 
J.K.: Staszek was very inspiring as he had access to many books and was happy to give me the titles of other items worth reading. With due justification, of course. He lent me some of them. I also bought books published outside of the censorship from the Barańczaks. Including the Workers' Defence Committee Newsletters in greater numbers. I was lucky because he had lent me for one night the first issue of Zapis, which was then typed in the A4 format. Of course, I particularly value his own volumes with dedications published outside of the censorship which he offered me at the time: Sztuczne oddychanie [Artifical Respiration] in a samizdat version (a typescript with handwritten corrections!), Tryptyk $z$ betonu, zmęczenia i śniegu [Triptych with Concrete, Fatigue and Snow], translations of Brodsky and Mandelstam.

What did we talk about? We discussed current events, we laughed at certain political issues. I remember that Staszek had a propaganda poster issued for the 30th anniversary of the Citizens' Militia and Security Service on his wall in the Kościuszki Street flat. We were obviously joking about this.

In the late 1970s, I worked at the Poznań Puppet and Actor Theatre. The job involved organising artistic work as well as advertising, and I spoke, for example, about how I took art programmes, playbills and posters to the censorship office in Mickiewicza Street. I gave accounts of my conversations with censors, including the story of a new poster not being approved for the Theatre because the visual artist designed it in B1 format. I was told that posters for a play titled Tygrysek i Koziołki z wieży ratuszowej [A Tiger and the Poznan Goats] could not appear in that format as it is reserved for mobilisation announcements only. These were quite grotesque matters, of which we laughed. I knew that Staszek was writing columns from the series of Ksiażki najgorsze [The Worst Books]. I once brought him a book of texts of the Gawęda scout group, which he also used in one issue of Biuletyn Informacyjny.

Years later, when I gained access to my file at the Institute of National Remembrance, I found in it transcripts or extracts from my wiretapped conversations with the Barańczaks. They were quite distant from the truth, and I was alleged to have promised Staszek to print some leaflets or materials outside of the censorship, because I had contacts with printing houses. I indeed had some contacts, but only as a client representing the puppet theatre. As it is known today, Security Service officers fabricated the contents of files so as to have a pretext to carry out some checks, 'describe risks', open new cases and have some topics for reporting.

My conversations with the Barańczaks were not strongly political in nature. We often talked about everyday matters, about books, I used to tell them, for example, various funny stories about actors and events in the theatre, Ania would attach rings to new curtains, we listened to music. Nevertheless, my visits were of interest to the Security Service. The authorities wanted to cut Barańczak off from all of his friends. This is why officers paid visits to my superiors at the Theatre.

K.K.: Did Barańczak mention the books that he dealt with in his essays, such as Escape from Freedom by Fromm or Bonhoeffer's letters, during the university classes which he conducted? 
J.K.: My studies in the field of Polish philology lasted four years, and not, as before and as today, five. The canon of reading has always been very extensive in Polish philology. At the time when the length of studies was officially shortened, which was part of the authorities' levelling policy, it became virtually impossible to read everything and discuss certain issues in class. In addition, further purely ideological subjects were introduced back then, taking up valuable time that could have been devoted to the discussion of major books. In the first year, Stanisław Barańczak had a one-hour weekly seminar with us on the literature of the interwar period. It was the academic year 1973/1974, thus referring to your question, Barańczak's text about Bonhoeffer may not have even been written back then. It was published in Student at the end of 1974. However, we heard about Fromm during those classes back then. It seems to me that it was at the time when we discussed the fascination of the Italian futurists with fascism. My second encounter with Barańczak as a lecturer took place at the end of my studies, when, shortly before his repressive dismissal from the university, he had a series of non-compulsory lectures on mass culture and popular literature in the autumn and winter of 1976. At that time, he spoke more broadly about the mechanisms of political persuasion, rhetoric, and it was invaluable for understanding the reality of the People's Republic of Poland and, of course, literature. He presented the concepts put forward by Fromm, American General Semantics, McLuhan or Morin; he spoke of books by Orwell and Klemperer, song lyrics and football banners. He drew examples from his own sketches from the cycle $\mathrm{Od}$ biorca ubezwłasnowolniony [Incapacitated Recipient] printed slightly earlier in the Poznań-based Nurt. These lectures were immensely popular. Barańczak was already a founding member of the Workers' Defence Committee and his writing was subject to censorship. I was extremely lucky to have been able to listen to those lectures as a young man. I still have notes from them.

Returning to your question, it is difficult for me to say whether, outside of the activities in which I participated, Barańczak had made references to Bonhoeffer and Fromm or analysed with students the attitudes of Naphta and Settembrini from The Magic Mountain before he was dismissed from Adam Mickiewicz University. I think this is very likely. His essays including Zapiski na marginesie Bonhoeffera [Notes on the Margins of Bonhoeffer] and Zmieniony głos Settembriniego [The Changed Voice of Settembrini] from the mid-1970s had a much wider intellectual impact: they were a certain projection and, at the same time, a project of the opposition's mental and ethical attitude towards the political reality of the time (I devoted a separate session paper to this issue).

K.K.: With reference to your paper, I would like to ask about the essay titled Zmieniony głos Settembriniego. You wrote that Barańczak treats fascism as a certain cognitive problem of the 20th century in this text. Why was it that The Magic Mountain became the inspiration for the programme sketch and not some of Mann's other works, such as Doctor Faustus? It seems that the latter novel, which deals with Nazi Germany, could well serve as a starting point for a reflection on worldview. 
J.K.: To be more precise, I wrote that both these essays speak of 20th century fascism. The text on Bonhoeffer obviously makes this clearer. As for the choice by Barańczak of The Magic Mountain, rather than the other book by Mann which you have mentioned: I should think that the figure of Naphta is extremely suggestive and firmly rooted in a certain reality, is a figure of an authoritarian personality, contrasting with the openness of a liberal such as Settembrini. This was probably the reason why Barańczak chose these characters for his deliberations. The path to this essay could have led both through The Magic Mountain by Mann and Fromm's Escape from Freedom published in Poland in 1970, where this type of personality was presented. Doktor Faustus by Mann makes, in turn, a reference to fascism in Germany through the prism of Faust by Goethe. Barańczak would probably not have been interested in adding some kind of third degree metaphor to this novel, which is somehow linked to the romantic fantasy of the German prototype. In the years before Zmieniony głos Settembriniego was written, several important books encouraging reflection on totalitarianism had been published in Poland, although they only seemingly referred to the realities of Nazi Germany. These included, apart from Escape from Freedom, Bonhoeffer's texts edited by Anna Morawska and her book about him titled Chrześcijanin w Trzeciej Rzeszy [A Christian in the Third Reich] as well as books by Stanisław Tyrowicz titled Światto wiedzy zdeprawowanej [The Light of Depraved Knowledge] or Bogusław Drewniak's Teatr i film Trzeciej Rzeszy [Theatre and Film of the Third Reich]. They all provided tools to analyse human attitudes in the conditions of the People's Republic of Poland and were important for the emerging opposition.

These two essays by Barańczak, ideological in a sense, were - as was often the case with his critical speeches - the forerunner of a new literary and political turning point. They preceded the events in Radom and Ursus and initiated the ethos of an independent writer, a paradigm of opposition literature, which was born in 1975-1976 together with Memorial 59, the establishment of the Workers' Defense Committee, underground publishing and the Zapis magazine. Barańczak's extraordinary ear for history was also revealed before the events of March 1968, when his article titled Nieufni i zadufani. Rzecz o walce romantyków z klasykami w poezji najnowszej [Distrustful and Conceited. A Thing about the Struggle of the Romantics with the Classics in the Latest Poetry] appeared less than a year before, and still earlier his pamphlet on Kazimiera Iłłakowiczówna's volume titled Szeptem [In a Whisper] was published. The notion of 'mistrust' became essential for both the new poetry and the participants of the March events. The draft Nieufni i zadufani was the founding text for the 1968 generation of poets, later referred to as the New Wave. In turn, a volume of poetry by Barańczak titled Tryptyk $z$ betonu, zmęczenia $i$ śniegu was published in the late 1970s, shortly before August 1980. In the most hopeless, final period of the decade of Gierek, it depicts in a few poems the monochromatic, winter aura, from beneath which flashes the gaudiness and wilderness of the natural world. Again, we are faced with some kind of a premonition of a breakthrough in the real world on the part of Barańczak, namely the outbreak of the "Solidarity" movement. And also with the first symptoms of a change in diction and poetic sensitivity. 
However, I would like to avoid talking about prophetism and putting Barańczak in the Romantic paradigm, as was the case with many scholars. If I were to look for the sources of this poet's intuition and forward-looking abilities, I would associate them with his extraordinary sensitivity to the exhaustion of the existing language for describing the world in the social space. It was, I suppose, the source of these predictions, when nothing had yet heralded the change in the visible sphere. The realised need to use a different, new language was a signal of the ongoing changes, a catalyst for new diagnoses and it generated new representations also in the area of essay writing for Barańczak. This is a separate problem which I have touched upon in the sketch O przepowiedniach Stanisława Barańczaka [On the Prophecies of Stanisław Barańczak] in the anthology titled Metafora - tekst - dyskurs [Metaphor - Text - Discourse].

K.K.: The question of God's presence in later volumes of Barańczak is indeed puzzling. In one of your sketches about this poet, you wrote that Barańczak would still like to have this dialogue with God in the scientific world. I wonder if, in a sense, it would not be possible to observe similar principles to those described by Miłosz in Ziemia Ulro [The Land of Ulro], yet leading to the opposite conclusions? It did happen that both poets looked at some issues in a different way, as evidenced by their rather minor dispute over how to read the poetry by Larkins. Where could Barańczak's need for this constant contact with the Absolute come from? Writing of Ziemia Ulro by Miłosz, he refers to himself as an agnostic.

J.K.: Perhaps by describing himself as an agnostic, Barańczak means his lack of faith in eschatology and the redemptive role of Christ. This is, however, an attempt to explain this world and to rise to the problem of why humankind is different from other creatures, from that background that exists outside it. Barańczak sees the divine element in the human being and it is this element that drives him in the poetic sense. This human duality is constantly returning, with good, love, altruism, sacrifice, cognitive expansiveness on the one hand, and evil, destruction, destructive fury on the other. The existence of both these potentials in an equally extreme, precisely divine intensity which is unknown to other creatures.

K.K.: Hence could the need to talk to God be simply a natural human need?

J.K.: In this concept of God, it is just inevitable that the human being asks questions and talks to Him. In any case, this dialogue is also very fruitful when it comes to poetry. Speaking of God in Barańczak's works, we are constantly moving in the space of a certain rationality. The poet firmly drew the line at mysticism, but never at metaphysics. I think that it is in this distinction that the key to reading his theological imagination lies. More broadly speaking, Barańczak belonged to the secular left, which, nevertheless, did not cut him off from theological reflection, paradoxically making this reflection non-imitative, renewing his thinking about God. Perhaps a priest 
who is in the current of mysticism is unable to say anything new about the Absolute that someone from outside the circle of people under constant religious influence is capable of saying. Barańczak could repeat the reflections of 17th-century English metaphysicians, and yet he has to explain it all to himself anew, as a modern man.

K.K.: And still, without any doubt many common points can be found, for example the figure of Deus Absconditus, the hidden God.

J.K.: Yes, researchers saw it quite early on. I think that poets and, more broadly, all artists have some certain cognitive impatience in them. Elevating the human being to the rank of a person worthy of talking to God is, as I said, very poetic. Many of Barańczak's works have a palimpsest structure, in which apparently ordinary, everyday matters are discussed, and it is only through more careful reading that one can see the deeper, metaphysical dimension of the situations described. In my book I wrote, for example, about an excellent poem titled Pierwsza piatka [The First Five], in which the hidden Genesis dimension can be seen.

K.K.: Are the previous volumes also worth analysing in a similar way?

J.K.: Yes, they are, particularly Tryptyk $z$ betonu, zmęczenia $i$ śniegu. I feel a need to write another sketch about this volume, which foreshadows, in a way, Barańczak's American poetry. There is not much linguism or carnivalisation known to the readers from the volumes titled Ja wiem, że to niestuszne [I Know it is Not Right] and Sztuczne oddychanie. It is possible to see in Tryptyk $z$ betonu, zmęczenia $i$ śniegu what will later characterise Barańczak's poetry: an increased receptivity to the world and intense descriptiveness present in his American poems, such as Atlantyda [The Atlantis] or Pan Elliot Tischler [Mr Elliot Tischler].

Interestingly, this volume is, in a sense, twinned with the later volume titled Podróż zimowa [Winter Journey]. Both collections are monochromatic: Tryptyk is dominated by the greyness of urban concrete whereas the whole landscape in Podróż zimowa is covered by snow. One volume was written just prior to the beginning of American life, while the latter is in a sense its coda, although it was followed by Chirurgiczna precyzja [Surgical Precision]. There is already a whole spectrum of colours in other poems written in the United States. It is possible to see all those incredible hues there, which must have struck someone who came to the USA from a socialist country.

K.K.: During the panel devoted to Barańczak, you argued that writing about Podróż zimowa today, the subject of illness-related suffering should be raised. Could I ask you to develop this thread?

J.K.: I have the feeling that this cycle is also, in a very intimate sense, a poetic response to the progressing disease of Barańczak, although of course there is no mention of the disease anywhere. 
In this volume I am most fascinated by a poem written to the melody of Schubert's third song:

\begin{abstract}
A może myśmy wcale nie mieli wznieść się nad ten jeden, ten widzialny, ten tymczasowy świat? ten taki sobie świat?
\end{abstract}

A może wzrost nad ziemię na metr z czymś lub sześć stóp to już wniebowstąpienie? Dopiero po nim grób?

I może tym niebiosom przez siedemdziesiąt zim zamilkłym z zimna głosem śpiewamy dźwięczny hymn, śpiewamy, dźwięczny hymn?

I może słowo „losem” w wersyfikacji zim tak z „lodem” jak i z „mrozem” poprawny tworzy rym, dokładny tworzy rym?
But what if we weren't destined at all to rise above this one, this visible, this temporary world? This mediocre world?

Perhaps just growing six feet Above the brittle earth Equates to our ascension? And only then the grave?

And what if we, our voices still for three score years and ten are singing to these heavens a rousing, soulful hymn? a rousing grateful hymn?

Perhaps the bleak word 'chilling', in winter poetry for 'thrilling' and for 'killing' would form a proper rhyme? would form a flawless rhyme?

"Growing six feet above the brittle earth" naturally refers to the height of an average person. I think that this poem contains a refreshing reflection that there will be no resurrection and that the short moment that is given to us on Earth is the best that could happen to us, that is our Ascension. It is possible to see in this thought how far Barańczak is moving away from this certain sensitivity that his poetry had in the domestic New Wave period, focused on a human being in the grey of an oppressive system, 'caught' in sadness or loneliness. I think there may be an element of self-persuasion in this recognition, an attempt to convince oneself that the world does not exist on account of the human being. Because of the autonomy of this world, all human claims make little sense. This kind of thinking is often triggered when a person suddenly realises that he or she will soon be gone.

K.K.: Are the works of Barańczak and the reflection contained in them still up-to-date today?

J.K.: It really depends on the sensitivity of each reader: one person will favour early Barańczak, another one will prefer his later works. In terms of

${ }^{1}$ The translation of the poem was retrieved from http://www.konieczny-napierala.art/ en/lyrics/ (access 30.09.2020.) 
the relevance of the world described in his poetry to the present day, later volumes are certainly much more up-to-date. Their greater attractiveness is also confirmed by the history of the reception of this poetry. On the other hand, I have the impression that Barańczak's diagnosis of life in the People's Republic of Poland is painfully up-to-date in some aspects. Wherever the mechanisms of conformism, aggressive propaganda, manipulation of emotions, a kind of political shamanism appear in public space today, those old, New Wave poems that look deep into the soul of the hero may turn out to be unexpectedly topical today.

Jerzy Kandziora - habilitated doctor, professor at the Institute of Literary Research of the Polish Academy of Sciences in Warsaw. His research interests focus on authors and literary phenomena entirely or partially burdened by an experience of the totalitarian system, settling accounts with the discussed system; authors, whose works require familiarity with the political contexts of post-war communism in Poland in order to be fully understood. Kandziora devoted his first book Zmęczeni fabuta [Tired by Fiction] (Wrocław 1993) to the diary-like autobiographical prose of Brandys, Konwicki and Woroszylski. The majority of the analysed works were either published outside Polish official system or in the West. Stanisław Barańczak, a poet representing the generation of 1968, since 1981 an émigré writing in the United States, is the protagonist of the monograph Ocalony w gmachu wiersza [Saved in the Edifice of the Poem] (2007). Jerzy Kandziora's latest book Poeta w labiryncie historii [A Poet in the Labyrinth of History] (2018) examines the literary roles of Jerzy Ficowski (1924-2006), distinct poet and scholar of the works of Bruno Schulz, whose creative activity is permeated by the spirit of freedom and intellectual independence. Kandziora's output also includes the bibliography Bez cenzury 1976-1989 [No Censorship 1976-1989] (1999; co-authors: Zyta Szymańska and Krystyna Tokarzówna), which he supervised. Covering literature, publishing and theatre, it registers the books and magazines (plus their content) put out by underground publishing houses in the People's Republic of Poland. The work received the Aleksander Brückner Scientific Award of the I Department of Social Sciences of the Polish Academy of Sciences in literature and philology.

E-mail: jerzy.kandziora@ibl.waw.pl

Karolina Król - a student of Polish philology at the Adam Mickiewicz University in Poznan. In 2019, she became a laureate of the 'Best Student Grant' programme and she carried out the project titled "Czesław Miłosz and Stanisław Barańczak: Parallels and Splits as Exemplified by the Reception of The Magic Mountain by Thomas Mann in the Works of the Two Poets." She is interested in the 20th- and 21st-century poetry as well as works centred around the issue of the Holocaust.

E-mail: karolina.krol@onet.pl 